\title{
Peduli kemanusiaan dan keutuhan ciptaan: Melacak pesan penatalayanan ciptaan di era pandemi
}

\author{
Yohanes Hasiholan Tampubolon ${ }^{1 *}$, Robi Prianto ${ }^{2}$, Aeron Sihombing ${ }^{3}$, Oferlin $\mathrm{Hia}^{4}$ \\ 1,2,3,4 Sekolah Tinggi Teologi SAPPI, Ciranjang, Indonesia \\ *Correspondence: jotampubolon@ymail.com
}

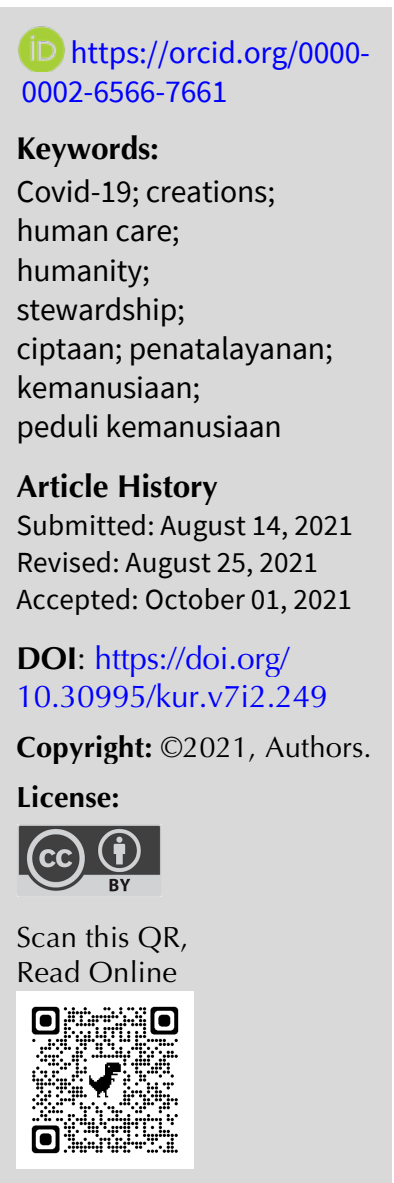

\begin{abstract}
The Covid-19 pandemic has hit the world and become a global problem today. Various theological responses are also present to interpret suffering, worship to pastoral care. However, this pandemic cannot be separated from the problem of the relationship between humans and other creations of God. Humanitarian issues and environmental problems are interrelated. So, there needs to be a theological reflection related to the integrity of creation in the midst of a pandemic. The author uses the term stewardship of creation to describe the relationship between humans and other creations of God. This article uses a descriptive-analytic research method with a qualitative approach. The author found that important themes in the Bible can encourage human involvement in the stewardship of creation even though there are certainly various challenges that will be faced.
\end{abstract}

Abstrak: Pandemi Covid-19 telah melanda dunia dan menjadi persoalan global saat ini. Berbagai respons teologispun hadir untuk memaknai mengenai penderitaan, peribadahan hingga pelayanan pastoral. Namun, pandemi ini tidak bisa dilepaskan dari persoalan relasi antara manusia dan ciptaan Allah lainnya. Persoalan kemanusiaan dan persoalan lingkungan saling berkelindan, sehingga, perlu ada refleksi teologis yang berkaitan dengan keutuhan ciptaan di tengah pandemi. Kajian ini menggunakan istilah penatalayanan ciptaan untuk menggambarkan relasi manusia dengan ciptaan Allah lainnya. artikel ini menggunakan metode penelitian deskriptif-analitik dengan pendekatan kualitatif. Apa yang ditemukan adalah, bahwa tema-tema penting dalam Alkitab bisa ditarik untuk mendorong keterlibatan manusia dalam penatalayanan ciptaan sekalipun tentu ada berbagai tantangan yang akan dihadapi.

\section{Pendahuluan}

Dunia saat ini masih berada dalam cengkeraman pandemi global. Covid 19 yang telah melanda negara dan benua dan menyebabkan penderitaan manusia yang tak terhitung, pergolakan sosial dan kerusakan ekonomi. Tetapi di saat penyebaran krisis saat ini belum pernah terjadi sebelumnya, Covid-19 memiliki kesamaan dengan sejumlah penyakit yang muncul dalam beberapa dekade terakhir, seperti Ebola, AIDS, SARS, flu burung, dan flu babi. Semua virus tersebut berasal dari hewan dan ada semakin banyak bukti bahwa eksploitasi alam yang berlebihan oleh manusia adalah salah satu faktor di balik penyebaran virus baru. ${ }^{1}$ Kesehatan bumi dan kesehatan manusia

${ }^{1}$ Damian Carrington, "Pandemics Result from Destruction of Nature, Say UN and WHO," The Guardian (London, June 2020), https://www.theguardian.com/world/2020/jun/17/pandemics-destruction-nature-un-wholegislation-trade-green-recovery. 
tidak bisa dipisahkan. Seperti yang Marthin Luther tuliskan, "We are caught in an inescapable network of mutuality, tied in a single garment of destiny. Whatever affects one directly, affects all indirectly." ${ }^{2}$ Manusia terjebak dalam hubungan jaringan mutualitas, perilaku manusia dapat berdampak pada semua secara langsung maupun tidak langsung.

$\mathrm{Hal}$ ini relevan dengan kondisi saat ini. Pandemi terjadi karena manusia merusak spesies lain untuk keuntungan komersil, keserakahan dan melakukan monokultur. Para pemimpin PBB, WHO dan WWF Internasional telah memeringati hal ini. ${ }^{3}$ Perdagangan satwa liar ilegal serta perusakan hutan menjadi kekuatan pendorong di balik meningkatnya jumlah penyakit yang berpindah dari satwa liar ke manusia. Hal ini mengakibatkan risiko penyakit, dan tentunya pandemi baru akan muncul bahkan lebih banyak dari sebelumnya. Hal tersebut tentu berpotensi untuk mendatangkan malapetaka pada kesehatan, ekonomi dan keamanan global. WWF pun mendorong pemimpin dunia untuk mengambil langkah tegas dan jelas untuk segera memperbaiki hubungan manusia dengan alam. Karena, ongkos yang dibayar untuk mencari solusi dan bertindak lebih murah dibanding akibat jika tidak bertindak.

Peluang patogen, seperti virus berpindah dari hewan liar dan peliharaan ke manusia pun dapat meningkat dengan perusakan dan modifikasi ekosistem alam tersebut. ${ }^{4}$ Virus, bakteri, dan mikroorganisme telah memainkan peran penting dalam kehidupan di Bumi selama 3,8 miliar tahun. ${ }^{5}$ Sebagian besar sama sekali tidak berbahaya dan seringkali penting untuk ekosistem dan kesehatan manusia, namun beberapa mikroorganisme, seperti bakteri dan virus patogen atau protozoa parasit, dapat memiliki efek negatif yang signifikan pada kesehatan manusia. Patogen dapat berubah dengan cepat, yang memungkinkan mereka berpindah dari hewan liar ke manusia. ${ }^{6}$ Perpindahan itu menyebabkan penyakit bagi manusia. Penyakit-penyakit yang muncul ini membahayakan nyawa manusia dan memiliki dampak kesehatan, sosial, ekonomi bahkan keamanan yang besar. Perilaku manusia dan faktor demografispun secara signifikan meningkatkan risiko ini, dan di tengah perkembangan sangat pesat alat transportasi menyebabkan penyebaran pandemi yang semakin tak terkendali.

Berdasarkan pengamatan terhadap beberapa artikel yang telah termuat di beberapa jurnal, topik-topik teologis yang diangkat mengenai Covid-19 adalah mengenai penderitaan ${ }^{7}$, ibadah ${ }^{8}$, pelayanan pastoral. ${ }^{9}$ Oleh karena itu, perlu memikirkan konsep teologi yang ramah bagi keutuhan ciptaan. Hal tersebut penting, karena Covid-19 tidak terlepas dari persoalan kerusakan lingkungan dan persoalan lingkungan akan menjadi persoalan kemanusiaan. Penelitian lingkungan yang berkaitan dengan Covid-19 masih belum diteliti. Di samping itu, tinjauan etis berdasarkan tema-tema penting dalam Alkitab belum pernah diuraikan lebih lanjut. Stevanus mendeskrip-

${ }^{2}$ Roy Money, "A Network of Mutuality," in In an Inescapable Network of Mutuality: Martin Luther King, Jr. and the Globalization of an Ethical Ideal, ed. Lewis V. Baldwin and Paul R. Dekar (Oregon: Cascade Books, 2013 ), 225.

${ }^{3}$ Carrington, "Pandemics Result from Destruction of Nature, Say UN and WHO."

${ }^{4}$ World Wildlife Fund, "The Loss of Nature and the Rise of Pandemics Protecting Human and Planetary Health," 2020, 4,

https://wwfeu.awsassets.panda.org/downloads/the_loss_of_nature_and_rise_of_pandemics__protecting_human_and _planetary_health.pdf.

${ }^{5}$ Fund, 4.

${ }^{6}$ Fund, 4.

${ }^{7}$ David Alinurdin, "Covid-19 Dan Tumit Achilles Iman Kristen," Veritas: Jurnal Teologi Dan Pelayanan 19, no. 1 (June 8, 2020): 1-9, https://doi.org/10.36421/veritas.v19i1.373.

${ }^{8}$ Roedy Silitonga, "Respon Gereja Atas Pandemik Corona Virus Desease 2019 Dan Ibadah Di Rumah," Manna Rafflesia 6, no. 2 (April 30, 2020): 86-111, https://doi.org/10.38091/man_raf.v6i2.125; Susanto Dwiraharjo, “Konstruksi Teologis Gereja Digital: Sebuah Refleksi Biblis Ibadah Online Di Masa Pandemi Covid-19," EPIGRAPHE: Jurnal Teologi Dan Pelayanan Kristiani 4, no. 1 (May 29, 2020): 1, https://doi.org/10.33991/epigraphe.v4i1.145.

${ }^{9}$ Lavandya Permata Kusuma Wardhani and Daniel Fajar Panuntun, "Pelayanan Pastoral Penghiburan Kedukaan Bagi Keluarga Korban Meninggal Coronavirus Disease 2019 (COVID-19)," KENOSIS: Jurnal Kajian Teologi 6, no. 1 (June 15, 2020): 43-63, https://doi.org/10.37196/kenosis.v6i1.98. 
sikan tinjauan etis tentang alam atau lingkungan hidup dengan landasan biblikal-teologis ${ }^{10}$; Katu melihat persoalan etis dari dimensi eskatologi Kristen ${ }^{11}$; Yuono membangun argumentasi etis melalui interpretasi terhadap teologi penciptaan. ${ }^{12}$ Kepedulian mengenai isu lingkungan perlu didorong di tengah Kekristenan (terutama kelompok Injili) di Indonesia. ${ }^{13}$ Pandemi saat inipun lebih dari sekadar masalah untuk diselesaikan. Sebaliknya, ini adalah momen untuk mempertimbangkan hubungan manusia yang rusak dengan ciptaan Allah lainnya, dan keterasingan kita dari tujuan dan makna hidup yang Allah berikan. Paper ini akan memaparkan mengenai hal tersebut, terutama tentang penatalayanan ciptaan, dan di bagian penutup dipaparkan mengenai tantangan yang dihadapi saat ini.

\section{Metode Penelitian}

Metode yang digunakan dalam tulisan ini adalah deskriptif-analitik; Penggunaan metode deskriptif ${ }^{14}$ dengan pendekatan kualitatif pada teks Alkitab. ${ }^{15}$ Kemudian, dilakukan analisis terhadap tema-tema penting dalam Alkitab untuk mendapatkan pesan penatalayanan bagi keutuhan ciptaan, dan menganalisis beberapa tantangan yang dihadapi. Metode deskriptif-analitik yang dimaksud adalah metode yang menekankan kepada usaha untuk memperoleh informasi mengenai objek yang diteliti, kemudian memberikan gambaran terhadap fenomena-fenomena yang terjadi, mencari hubungannya, dan menarik makna dari suatu masalah yang diinginkan. Tahapan penelitian yang dilakukan adalah: menemukan masalah berdasarkan fenomena yang terjadi terkait dengan kerusakan alam, yang berdampak pada kesehatan manusia sehingga perlu adanya refleksi teologis; membaca beberapa teks-teks dalam Alkitab yang berhubungan dengan tema-tema penting dalam Alkitab; melalui pendekatan hermeneutik, menemukan beberapa pesan penatalayanan bagi keutuhan ciptaan dan menyusunnya secara teratur; di bagian terakhir, memaparkan berdasarkan berbagai kajian literatur untuk menemukan beberapa tantangan yang dihadapi dalam penatalayanan ciptaan.

\section{Hasil dan Pembahasan \\ Penatalayanan Ciptaan}

Pengertian penatalayanan secara umum adalah asisten bagi orang yang memiliki kewenangan sebagai pelaksana kehendaknya. ${ }^{16}$ Dalam artikel ini, tentu kewenangan tersebut diberikan Allah kepada manusia. sedangkan manusia bertanggung jawab untuk memainkan perannya dalam relasi manusia dengan ciptaan lainnya. ${ }^{17}$ Pada awalnya, Allah memanggil manusia untuk bertanggung jawab atas bumi dan segala isinya. Manusia bertanggung jawab untuk melaksanakan kehendak Allah untuk dunia dan segala isinya, bukan sebagai pemilik yang bisa sebebasnya me-

\footnotetext{
${ }^{10}$ Kalis Stevanus, "Pelestarian Alam Sebagai Perwujudan Mandat Pembangunan: Suatu Kajian Etis-Teologis," KURIOS (Jurnal Teologi Dan Pendidikan Agama Kristen) 5, no. 2 (2019): 101.

${ }^{11}$ Jefri Hina Remikatu, "Teologi Ekologi: Suatu Isu Etika Menuju Eskatologi Kristen," CARAKA: Jurnal Teologi Biblika Dan Praktika, 2020, 67, https://doi.org/10.46348/car.v1i1.12.

${ }^{12}$ Yusup Rogo Yuono, "Etika Lingkungan : Melawan Etika Lingkungan Antroposentris Melalui Interpretasi Teologi Penciptaan Yang Tepat Sebagai Landasan Bagi Pengelolaan-Pelestarian Lingkungan," FIDEI: Jurnal Teologi Sistematika Dan Praktika, 2019, 183, https://doi.org/10.34081/fidei.v2i1.40.

${ }^{13}$ Yohanes Hasiholan Tampubolon, "Refleksi Kepedulian Injili Pada Isu Lingkungan Hidup," Stulos 18, no. 1 (2020): 53-76.

${ }^{14}$ Otieli Harefa, "Mplikasi Teologis Baptisan Air Pada Keselamatan," PASCA: Jurnal Teologi Dan Pendidikan Agama Kristen 16, no. 1 (May 29, 2020): 3, https://doi.org/10.46494/psc.v16i1.78.

${ }^{15}$ Grace Emilia, "Afeksi Dalam Teologi Jonathan Edwards Serta Implementasinya Dalam Kehidupan Kristen," PASCA: Jurnal Teologi Dan Pendidikan Agama Kristen 16, no. 2 (November 5, 2020): 82, https://doi.org/10.46494/psc.v16i2.112.

${ }^{16}$ Derek J. Tidball, Teologi Penggembalaan (Suatu Pengantar) (Malang: Gandum Mas, 2020), 99.

${ }^{17}$ Ken Gnanakan, Responsible Stewardship of God's Creation (New York: World Evangelical Alliance, 2014), 103.
} 
manfaatkan apa ada di bumi, melainkan sebagai hamba/pekerja yang bertanggung jawab mengatur dan mengelola apa yang dimiliki tuannya.

Penatalayanan merangkum dua sisi relasi manusia; di satu sisi hubungan dengan Allah, di sisi lain, hubungan dengan sesama manusia. ${ }^{18}$ Lebih tepatnya penatalayanan merangkum keterkaitan manusia hubungannya dengan yang bukan manusia, bisa saja makhluk hidup dan bendabenda lainnya. Benda-benda lainnya tersebut bisa saja harta milik yang sering juga dikaitkan dengan istilah penatalayanan. Manusia disini tidak otonom dan bertindak sebebasnya dalam relasinya dengan yang lain.

Prinsip teologisnya, bahwa Allah adalah pencipta yang memiliki dan memerintah atas seluruh yang ada, ini bisa dilihat dari kisah penciptaan dan juga seluruh bagian Perjanjian Lama. Seperti yang tertulis dalam kitab Mazmur: "Tuhanlah yang empunya bumi serta segala isinya, dan dunia serta yang diam di dalamnya" (Maz. 24:1), begitu juga yang dikatakan Allah kepada Ayub: "Apa yang ada di seluruh kolong langit adalah kepunyaanKu" (Ayb. 41:2), dan di dalam bagianbagian Alkitab lainnya.

Jadi, penatalayanan yang dimaksudkan berarti manusia perlu tunduk kepada Allah dalam mengelola dan mengatur apa yang ada di bumi ini, karena manusia adalah ciptaan, bukan Allah. Yang kedua, wewenang itu tidak mutlak, karena umat Israel lebih diibaratkan sebagai pekerja bukan pemilik. Di negeri mereka, mereka dikategorikan sebagai orang asing dan pengembara, sebab negeri itu adalah negeri Allah pada akhirnya (Im. 25:23), apapun yang dikerjakan harus mempertanggung jawabkannya kepada Allah. Prinsip lainnya manusia bertanggung jawab kepada Allah atas kesejahteraan sesamanya, serta apa yang dimiliki, baik itu kekayaan dan kuasa tidak boleh dipakai untuk merugikan mereka yang miskin (Am. 4:1-3; 5:11, dsb).

Contoh mandat penatalayanan manusia yang teraplikasi juga dalam prinsip diatas adalah tahun Yobel. Dalam tahun Yobel, kekayaan alam tidak boleh untuk segelintir orang, namun dibagikan seluas mungkin. ${ }^{19}$ Kekayaan harus dibagikan secara cuma-cuma kepada siapa pun yang membutuhkan, tugas manusia sebagai pekerja Allah adalah mendistribusikan kekayaan alam tersebut secara merata. Tugas manusia di hadapan kekayaan alam bukanlah untuk melipatgandakan kekayaan pribadi atau mengeksploitasinya sesuka hati.

Penatalayanan itu sendiri muncul sebagai gagasan dalam isu lingkungan pada pertemuan London tahun 1999. John Houghton menulis bahwa beberapa orang mengira bahwa penggunaan kata penatalayanan cenderung terlalu antroposentris dan menimbulkan kesan yang menyesatkan mengenai hubungan manusia dengan lingkungannya. ${ }^{20}$ Namun, persoalan istilah dan relevansi etisnya bukanlah satu-satunya aspek penting dalam meresponi persoalan lingkungan ${ }^{21}$, karena masih ada aspek pengalaman langsung dan pengumpulan data (sains) dan harus meletakkan pengetahuan yang koheren dengan dunia, dan menunutun kepada kehidupan dalam praktik (praksis). ${ }^{22}$ Dalam pembahasan selanjutnya akan melihat pada aspek etika yang diperoleh dalam tema-tema penting di Alkitab.

\section{Penatalayanan Ciptaan dalam Alkitab}

Pada bagian ini akan dipaparkan dasar dalam Alkitab berdasarkan beberapa tema penting, seperti: penciptaan, perjanjian, penebusan, dan akhir zaman.

\section{Penciptaan}

Pada mulanya Allah yang mencipta segala sesuatu; la adalah Tuhan dari semua. Tidak hanya mencipta, la juga terus menerus menopang ciptaan. Oleh karena itu, sebagai ciptaannya, manu-

\footnotetext{
${ }^{18}$ John Hall Douglas, The Steward: A Biblical Symbol Come of Age (Grand Rapids: Eerdmans, 1990), 67.

${ }^{19}$ Donald Kraybill, Kerajaan Yang Sungsang (Jakarta: BPK Gunung Mulia, 2005), 126.

${ }^{20}$ Murray Rae, "To Render Praise: Humanity in God's World," in Enviromental Stewardship, ed. Robert James Berry (Edinburgh: T\&T Clark, 2006), 291.

${ }^{21}$ Yohanes Hasiholan Tampubolon, "Telaah Kritis Etika Lingkungan Lynn White," TE DEUM (Jurnal Teologi Dan Pengembangan Pelayanan), 2020.

${ }^{22}$ Calvin B. DeWitt, "Stewardship: Responding Dynamically to the Consequences of Human Action in the World," in Enviromental Stewardship (London: T\&T Clark, 2006), 150.
} 
sia harus mempunyai komitmen yang sama dengan kepedulian terhadap ciptaan Allah. Penciptaan memperlihatkan dimensi trasendensi dan imanensi dari Allah. Imanensi bisa dimaknai bahwa la dekat dengan ciptaan-Nya. Imanensi pula dapat dimaknai bahwa la hadir dalam alam ciptaan-Nya dan peduli terhadapnya, namun, la trasenden, berbeda dari ciptaan.

Dalam Kejadian 1, Allah bekerja secara kreatif melalui creatio ex nihilo: penciptaan dari yang tidak ada. Konsep itu bermakna bahwa Allah adalah sumber segala sesuatu, sehingga bertanggung jawab untuk semua yang dibuat. ${ }^{23}$ Doktrin Alkitab ini membantah bentuk panteisme yang membentuk relasi tidak Alkitabiah antara pencipta dengan ciptaan, demikian juga dualisme yang mengklaim adanya konfrontasi antara Allah yang baik dan penciptaan yang jahat. Allah mencipta dan terus menerus berhubungan dengan ciptaan-Nya. Kedekatan (imanensi) dan jarak (trasendensi) memberikan kepada Allah dan ciptaan-Nya interelasi tapi tidak melepaskan identitasnya. $^{24}$

Di dalam kitab Kejadian dinyatakan sebanyak enam kali, bahwa apa yang Allah ciptakan adalah "baik". Kebaikan ciptaan ini harus digarisbawahi dalam rangka bagi manusia untuk mempunyai sikap penghargaan terhadap alam. ${ }^{25}$ Manusia tidak dapat mengatakan: "Tuhan itu baik dan telah memberikan segala sesuatu yang la ciptakan untuk kami!", namun mempraktekkan eksploitasi ciptaan untuk keuntungan segelintir orang dan mengabaikan kebaikan untuk keutuhan dan keberlanjutan ciptaan.

Kebaikan yang Allah ciptakan menyiratkan bahwa kejahatan bukan merupakan bagian yang melekat dari penciptaan. Sedangkan, paham dualisme membuat penciptaan menjadi jahat dan Tuhan yang baik berada pada dua oposisi bertentangan. Di posisi lainnya, panteisme akan menyanjung kebaikan dari penciptaan hingga hampir menyejajarkan Allah dan ciptaan ${ }^{26}$ serta realitas kejahatan dan penderitaan dianggap ilusi. Namun, Alkitab pula menggambarkan kejahatan dan penderitaan seperti dalam masa pandemi saat ini adalah kenyataan. Penderitaan dan kejahatan telah menjadi bagian dari ciptaan sendiri. Semua ciptaan adalah baik, tetapi dosa telah "menerobos" kebaikan ini. Hal ini adalah konsekuensi dari dosa yang harus diterima manusia (Kej. 3: 17-18; 9: 2).

Kebaikan juga menyiratkan, bahwa ada nilai yang melekat dalam penciptaan dan bukan hanya demi kesejahteraan manusia. Beberapa ahli ekologi dan lingkungan telah menyerukan pengakuan dari nilai intrinsik melalui sikap biosentris dan ekosentris, sedangkan teologi kristen dituduh antroposentris. Ada beberapa kebenaran dalam tuduhan ini. ${ }^{27}$ Harus diakui, kehancuran ekologis, muncul akibat manusia mengukur segala sesuatu dari segi maksimalisasi keuntungan. ${ }^{28}$ Termasuk dalam ciptaan, karena menghargai ciptaan, akibatnya manusia justru mengeksploitasi ini untuk diri sendiri. ${ }^{29}$ Sikap ini perlu ditolak demi keberlangsungan hidup manusia dan keberlanjutan semua ciptaan. Manusia harus menerima tanggung jawab sebagai penatalayan untuk memastikan masa depan yang berkelanjutan bagi semua ciptaan.

Kebaikan juga menjelaskan kasih karunia dan keindahan ciptaan Allah. ${ }^{30}$ Kata Ibrani dapat diterjemahkan "baik" serta "indah". Tuhan, dengan kreativitas seorang seniman ulung, melukiskan gambaran yang tak ternilai dan hadiah ini dalam kasih karunia untuk manusia. Anugrah atau

${ }^{23}$ Gnanakan, Responsible Stewardship of God's Creation, 23.

${ }^{24}$ Gnanakan, 27.

${ }^{25}$ Ledy Manusama, "Allah Dan Alam," KENOSIS: Jurnal Kajian Teologi 1, no. 2 (2015): 200, https://doi.org/https://doi.org/10.37196/kenosis.v1i2.28.

${ }^{26}$ Irene Ludji, "Spiritualitas Lingkungan Hidup: Respon Iman Kristen Terhadap Krisis Ekologi," in Respon Agama Kristen Terhadap Kerusakan Lingkungan (Yogyakarta: UKSW, 2014), 69.

${ }^{27}$ Tampubolon, "Telaah Kritis Etika Lingkungan Lynn White."

${ }^{28}$ John Alexander, "Environmental Sustainability versus Profit Maximization: Overcoming Systemic Constraints on Implementing Normatively Preferable Alternatives," Journal of Business Ethics, 2007, 155, https://doi.org/10.1007/s10551-006-9264-5.

${ }^{29}$ Gnanakan, Responsible Stewardship of God's Creation, 27.

${ }^{30}$ Gnanakan, 27. 
karunia ini dikembalikan bagi kemuliaan Allah. Allah mengharapkan pelayanan yang bertanggung jawab dari manusia.

\section{Perjanjian}

Di samping penciptaan, tema penting dalam Alkitab adalah perjanjian. Pada dasarnya perjanjian adalah janji antara dua pihak yang terikat sumpah. Kata umum yang digunakan dalam Perjanjian Lama adalah berit. Istilah 'perjanjian' pertama kali muncul di Kejadian 6:18 yang menunjukkan perjanjian Allah dengan Nuh sebelum air bah: "Tetapi dengan engkau Aku akan mengadakan perjanjian-Ku, dan engkau akan masuk ke dalam bahtera itu: engkau bersama-sama dengan anak-anakmu dan isterimu dan isteri anak-anakmu." Dalam kisah tersebut dapat tergambarkan istilah perjanjian yang berbeda dengan istilah pada umumnya. Perjanjian antara Allah dan Nuh bukanlah perjanjian kesepakatan antara dua pihak yang setara. Perbuatan Allah menunjukkan kedaulatan dan kasih karunianya kepada Nuh. Allah sebagai pihak yang meneguhkannya.

Perjanjian itu diawali dari dosa manusia yang ketika itu sudah sangat berat. Dosa berdampak pada seluruh aspek kehidupan. Allah kemudian berinisiatif untuk menghukum manusia. Perjanjian Allah dengan Nuh seringkali disebut eko-kovenan karena memiliki keprihatinan tentang keseluruhan ciptaan. Setelah banjir, Allah berjanji untuk tidak mengutuk bumi lagi seperti yang pernah dilakukan (Kej. 8:21). Allah peduli pada keberlanjutan ciptaan-Nya. Allah pula mengulangi perintah untuk beranak cucu dan memenuhi bumi (Kej. 9:1). Kisah tersebut menunjukkan Allah adalah Tuhan atas ciptaan. Sebagai Tuhan, ia menuntut ketaatan manusia dan teraktualisasi dalam seluruh aspek kehidupan, baik itu hubungan antara manusia dan ciptaan Allah lainnya. Hubungan manusia dan ciptaan/lingkungan saling berkaitan. Manusia dapat memengaruhi alam ciptaan, namun alam ciptaan juga dapat mempengaruhi kesejahteraan manusia. Hal inilah yang terjadi di masa pandemi sekarang ini. Oleh karena itu, manusia tidak bisa berelasi secara eksploitatif dengan alam ciptaan. Allah pula memberikan pembatasan bagi manusia, contohnya manusia dilarang memakan daging yang masih ada nyawanya atau darahnya (Kej. 9:4). Allah memiliki perhatian kepada ciptaan lain/non-manusia.

Perjanjian Allah dan Nuh memberikan referensi bagi sikap manusia terhadap ciptaan bukan manusia. Manusia harus menghormati apa yang telah Allah berikan. Manusia bukanlah makhluk otonom dan tanpa bertanggung jawab memanfaat apa yang telah Allah berikan. Melalui perjajian juga dapat terlihat bahwa alam turut bersaksi atas kesetiaan Allah (Kej. 9:13; 9:17). Dalam perjanjian ini terlihat bahwa manusia bukan satu-satunya penerima. Ada pula tempat bagi ciptaan non-manusia di mana Allah menjamin pelestarian dan keberlanjutannya. Dosa manusia berdampak pada seluruh ciptaan, perjanjian Allah juga berlaku serupa.

Selain perjanjian Nuh, adapula perjanjian Allah kepada bangsa israel mengenai tanah (Kej. 12:2-3). Dari kisah Perjanjian tersebut dapat terlihat bahwa: Allahlah pemilik tanah (Im. 25:23) dan diatas tanah dilaksanakan tuntutan Allah melalui hukum-hukumnya dan menuntut menjaga juga merawat untuk generasi yang akan datang (Im. 25:4). Tanah tidak untuk dijual dalam jangka waktu yang lama tetapi dapat dimiliki sementara hingga tahun Yobel, maka, secara otomatis akan kembali ke pemilik asli (Im. 25:13-17). Manusia sebagai "penyewa" mensyaratkan tanggung jawab dan mendistribusikan tanah dengan adil dan tepat (UI. 28:1-14). Hal ini bertentangan dengan saat ini yang sedikit orang memiliki tanah dalam sekala besar dan sebagian lainnya tidak memiliki tanah. Bahkan tanah yang dimiliki tersebut dieksploitasi untuk mendapatkan keuntungan (profit). Tanah sebagai alat produksi harus menyejahterakan semua orang. Orang miskin diizinkan untuk memetik gandum dan pemiliki harus mengijinkan mereka mengumpulkan sisa-sisa makanan dari panen (UI. 23:24-25; Im. 19:9-10). Konsep berbagi seakan menjadi bagian integral dari perjanjian.

Perjanjian dalam Alkitab tentunya masih relevan dengan berbagai isu ekonomi, politik, etika dan sosial saat ini. Baik itu berurusan dengan tanggung jawab masyarakat (UI. 3:13-22), komitmen keluarga (UI. 4:9-10) atau perintah individu, dapat memberikan kontribusi konkret untuk situasi kontemporer. Pesan-pesan tersebutpun dapat ditarik ke permasalahan-permasalahan lingkungan kontemporer. Misalnya, dalam Ulangan 23:9-14 yang berkaitan dengan kesehatan priba- 
di dan masyarakat, dapat pula ditarik di tengah konteks pandemi yang mengancam kesehatan manusia. Prinsip-prinsip Alkitab tersebut dapat diterapkan pada masa kini sekalipun tidak secara harafiah ditafsirkan.

\section{Penebusan}

Setelah kejatuhan manusia ke dalam dosa, gambar dan rupa Allah rusak. Pemulihan dilakukan Allah dengan mengutus anak-Nya, Yesus Kristus. Apa yang telah gagal dalam kehidupan Adam, diperbaharui dan disempurnakan oleh Yesus. Deklarasi Injili tentang perawatan ciptaan memaparkan bahwa karena di dalam Kristus telah menyembuhkan keterasingan manusia dari Allah dan memberikan kepada manusia buah pertama dari rekonsiliasi segala sesuatu, manusia kemudian berkomitmen untuk bekerja dalam kuasa Roh Kudus untuk membagikan Kabar Baik Kristus dalam perkataan dan perbuatan, Untuk rekonsiliasi semua orang di dalam Kristus dan untuk memperluasnya kepada ciptaan lainnya yang menderita. ${ }^{31}$ Rekonsiliasi yang Allah kerjakan tidak hanya bagi manusia tetapi segala sesuatu: "Kristus itu harus tinggal di sorga sampai waktu pemulihan segala sesuatu, seperti yang difirmankan Allah dengan perantaraan nabi-nabi-Nya yang kudus di zaman dahulu" (Kis. 3:21). Penebusan di dalam Yesus menghasilkan rekonsiliasi segala sesuatu. Begitu pula di dalam Roma 8:18-22, bahwa ciptaan mengerang memohon penebusan dari Tuhan. Paulus melihat bahwa semua ciptaan Allah akan menikmati karya penebusan Kristus. Dalam kitab Wahyu, Yohanes juga mevisualisasikan langit dan bumi yang baru sebagai bentuk pemulihan dari keseluruhan ciptaan.

\section{Akhir Zaman}

Dengan dipulihkannya tanggung jawab manusia melalui penebusan yang dikerjakan Kristus, maka akan terjadi penciptaan kembali atas seluruh ciptaan baik itu manusia dan bukan manusia. Artinya, penebusan ini akan berdampak langsung pada penciptaan kembali keutuhan ciptaan. Pola seperti ini, sesungguhnya dapat dilihat dari narasi Nuh (air bah), setelah penghancuran bumi dan segala isinya, Allah menciptakan kembali bumi dan isinya menjadi baru (Kej. 9:8-17). Selanjutnya, di sepanjang Perjanjian Lama, negeri atau tanah yang terancam hilang, akhirnya diberikan kembali dalam keadaan baru kepada umat Allah. Konsep ini terus berlanjut sampai Perjanjian Baru, di mana Kristus hadir dan membawa pembaruan kembali ciptaan-Nya. Penciptaan kembali ini seharusnya dilihat dalam kerangka perjanjian yang Allah buat antara diri-Nya dan manusia, yang kemudian dimateraikan dengan menaruh busur-Nya (pelangi) sebagai tanda perjanjian antara Allah dan segala mahluk hidup yang ada di bumi.

Penciptaan kembali adalah hasil akhir dalam seluruh skema penyelamatan Allah atas seluruh ciptaan-Nya. Ini adalah sebuah realita di mana anugerah Allah akhirnya akan menyentuh seluruh ciptaan-Nya. Meski manusia adalah target utama penebusan Allah, dan keselamatan itu dimulai dari manusia, Allah tidak ingin keselamatan itu hanya eksklusif dialami oleh manusia. la ingin agar manusia juga membagikan anugerah-Nya bersama kepada ciptaan yang lain, menebus masyarakat, dunia binatang, dan bahkan bumi itu sendiri. ${ }^{32}$ Proses bergeraknya kekuatan anugerah dari titik manusia ke titik-titik ciptaan Allah yang lain akan terus berlangsung di sepanjang sejarah manusia dan bumi ini sampai menuju akhir sejarah itu.

Akhirnya, dalam perspektif eskatologis, garis penebusan manusia dan lingkungan hidupnya akan bersinggungan dengan garis kekekalan di akhir zaman. Alkitab menyaksikan akan ada saat di mana semua mahluk akan masuk ke dalam "kemerdekaan kemuliaan anak-anak Allah" (Rm. 8:19-22) di dalam "langit dan bumi" yang baru (Why. 21:1-8). Keadaan ini akan terjadi ketika Allah akan mengarahkan seluruh ciptaan ini kepada suatu pemenuhan akhir, kebangkitan kemanusiaan yang tertebus dan kemerdekaan semua ciptaan. Dasar dari pengharapan ini adalah

\footnotetext{
${ }^{31}$ General Es, "WEA GA Statement - On the Care of Creation," World Evangelical Alliance, 2008, https://worldea.org/es/news/wea-ga-statementon-the-care-of-creation/.

${ }^{32}$ Michael Wittmer, Heaven Is A Place On Earth (Grand Rapids: Zondervan Publishing, 2004), 188.
} 
karena kebangkitan Kristus adalah "buah pertama" dari kemerdekaan ini. ${ }^{33}$ Puncak dari pengharapan eskatologis ini tidak akan terjadi di dalam bumi yang sekarang, tetapi sebagaimana visi kenabian PL dan pengharapan eskatologis PB, akan menemui penggenapannya di dalam realitas langit dan bumi yang baru, yaitu Eden yang telah ditebus. ${ }^{34}$

\section{Tantangan yang Dihadapi}

Berbagai tema penting dalam Alkitab memiliki implikasi bagi penatalayanan ciptaan. Namun, untuk terlibat dalam kepedulian penatalayanan bukanlah tanpa tantangan; tantangan hadir dari berbagai sisi. Moltmann berpendapat bahwa persoalan lingkungan tidak dapat terpisah dari persoalan sosial, ia menegaskan istilah krisis ekologis adalah deskripsi yang kurang akurat mengenai fakta sebenarnya, ini adalah krisis keseluruhan sistem kehidupan dunia di zaman industri modern. ${ }^{35} \mathrm{Hal}$ ini terkait dengan corak produksi masyarakat dan kondisi sosial di era globalisasi. ${ }^{36}$ Duchrow dan Liedke melihat faktor penyebab yang berbeda. Mereka berpendapat krisis lingkungan dapat diatasi dengan menghilangkan distingsi antara manusia dan alam. ${ }^{37}$ Melalui perombakan cara pandang keagamaan terhadap alam, persoalan lingkungan diharapkan dapat teratasi. Pendekatan tersebut pula yang menjadi kerangka analisa Lynn White terhadap akar kerusakan lingkungan.

Oleh karena banyaknya faktor yang memengaruhi persoalan lingkungan, beberapa tantangan yang dihadapi dipaparkan di sini; pertama, tantangan ekonomi. Di era pemerintahan Jokowi, untuk menstimulasi persaingan negara Indonesia di era global, pemerintah menuntut pertumbuhan ekonomi dengan berbagai kebijakan. Kebijakan yang dilakukan adalah melalui pembangunan, perindustrian, pariwisata dan fasilitas fisik lainnya untuk mendukung perputaran roda ekonomi. Indonesia juga bisa dikatakan terlambat merespons pandemi karena sempat mendorong sektor pariwisata dengan cara memberikan diskon bagi para turis pada masa awal pandemi ${ }^{38}$, bahkan mengorbankan buruh untuk memperjuangkan hak-haknya dan potensi memperparah kerusakan lingkungan dengan mengesahkan UU Cipta Kerja di masa pandemi agar mampu menarik investor menanam modalnya di Indonesia. ${ }^{39}$

Kedua, berkaitan dengan agama. White memberikan teguran keras terhadap Protestanisme. Protestanisme, menurut White, menjadi akar kerusakan lingkungan karena pengajaran yang antroposentris. Tafsiran White mengenai akar kerusakan lingkungan-yang menurutnya diakibatkan oleh orang-orang Kristen berdasarkan legitimasi ajaran Alkitab ${ }^{40}$-mengikutsertakan keprihatinan Kekristenan terhadap keberlanjutan lingkungan/ciptaan.

\footnotetext{
33“'Evangelical Christianity and The Environment' World Evangelical Fellowship Theological Commission Unit on Ethics and Society/Au Sable Forum Summarizing Committee Report," Transformation: An International Journal of Holistic Mission Studies 9, no. 4 (October 1992): 27, https://doi.org/10.1177/026537889200900410.

34"'Evangelical Christianity and The Environment' World Evangelical Fellowship Theological Commission Unit on Ethics and Society/Au Sable Forum Summarizing Committee Report," 27.

${ }^{35}$ Jürgen Moltmann, God in Creation: A New Theology of Creation and the Spirit of God, Gifford Lectures ; 1984-1985, 1991, 23.

${ }^{36}$ Clive William Ayre, An Approach to Ecological Mission in and Through the Christian Community in Australia: Beyond Apathy to Committed Action (Queensland: University of Queensalnd, 2008), 56.

${ }^{37}$ Ulrich Duchrow and Gerhard Liedke Shalom, Biblical Perspectives on Creation, Justice \& Peace (Manila: WCC Publication, 1989), 50.

${ }^{38}$ Andhika Prasetia, "Genjot Pariwisata Di Tengah Corona, Jokowi Beri Turis Diskon," Detiknews, February 2020, https://news.detik.com/berita/d-4903193/genjot-pariwisata-di-tengah-corona-jokowi-beri-turis-diskon.

${ }^{39}$ Osgar Sahim Matompo and Wafda vivid Izziyana, "Konsep Omnibus Law Dan Permasalahan RUU Cipta Kerja," Rechstaat Nieuw (Aturan Hukum Baru), 2020; Indonesia Center Environmental Law, "Pelemahan Instrumen Perlindungan Dan Pengelolaan Lingkungan Hidup Dalam RUU Cipta Kerja," Pelemahan Instrumen Perlindungan Dan Pengelolaan Lingkungan Hidup Dalam RUU Cipta Kerja, 2020; Astrid, "Omnibus Law (RUU Cipta Kerja) Untuk Siapa?," Omnibus Law (RUU Cipta Kerja) Untuk Siapa?, 2020; Ani Sri Rahayu, "Omnibus Law Cipta Kerja Atau Cilaka?," Arsip Publikasi Ilmiah Biro Administrasi Akademik, 2020; Fajar Kurniawan, "Problematika Pembentukan RUU Cipta Kerja Dengan Konsep Omnibus Law," Jurnal Panorama Hukum, 2020, https://doi.org/10.21067/jph.v5i1.4437.
} 
Selain pengajaran yang antroposentris, Kekristenan pula seringkali terjebak dalam dualisme antara spiritual dan material. Hal yang spiritual dianggap lebih penting dibandingkan kenyataan di dunia. Rodriguez menuliskan di dalam jurnal Global Bioethics risetnya di Filipina. la memaparkan bahwa kekristenan mempengaruhi kebudayaan di sana. Kekristenan yang dibawa oleh misionaris dari Eropa membuat masyarakat menjadi fatalistik yang menganggap apa yang terjadi sepenuhnya adalah kehendak Tuhan dan tidak perlu diubah. ${ }^{41}$ Fatalisme ini menjadikan masyarakat miskin tetap miskin, ideologi yang menjaga masyarakat miskin tetap subordinat dan menggantungkan kehidupannya dengan yang lain. Selain berdampak pada kehidupan sosio-ekonomi, fatalisme juga membuat kolonialis dengan mudah mengeruk kekayaan alam di Filipina yang mengakibatkan kerusakan hutan disana.

Ketiga, budaya, di tengah ekonomi global kapitalisme saat ini, manusia menilai segala sesuatu secara ekonomistik. Masyarakat pula diharuskan untuk bersaing demi menjalankan motor kehidupan. Tidak heran zaman sekarang disebut sebagai zaman individualisme dan materialisme. Kerusakan alam yang mengancam masa depan manusiapun seakan tidak menjadi persoalan. Kerusakan tersebut kemungkinan memang tidak dirasakan generasi saat ini. Namun, generasi yang akan datang akan merasakan dampaknya. Pengerukan kekayaan alam yang besar-besaran pun dianggap sebagai kewajaran. Kepentingan mengakumulasi kekayaan dianggap demi menjalankan roda peradaban.

\section{KESIMPULAN}

Persoalan pandemi Covid-19 saat ini tidak terlepas dari persoalan kerusakan lingkungan yang semakin massif pasca revolusi industri pertama. Oleh karena itu, perlu adanya refleksi etisteologis di masa pandemi yang berkaitan dengan hubungan manusia dan ciptaan Allah lainnya. Melalui tema-tema penting dalam Alkitab, seperti penciptaan, perjanjian, penebusan dan akhir zaman, dapat membangun etika penatalayanan bagi keutuhan ciptaan Allah. Tentunya konsep etis tesebut perlu dibenturkan dengan kenyataan dengan segala tantangan yang dihadapi di Indonesia saat ini.

Tema penciptaan dalam Alkitab menyadarkan manusia bahwa Allah pencipta segala sesuatu, dan manusia harus bertanggung jawab mengelola apa yang dipercayakan oleh Allah. Dalam tema perjanjian terlihat bahwa manusia bukanlah makhluk eksklusif satu-satunya yang diberikan perjanjian, namun, perjanjian Allah juga diberikan kepada ciptaan non-manusia lainnya. Hal tersebut memberikan referensi bagi sikap manusia terhadap ciptaan bukan manusia. Melalui perjajian juga dapat terlihat bahwa alam turut bersaksi atas kesetiaan Allah. melalui tema penebusan yang ada dalam Alkitab mengajarkan bahwa rekonsiliasi yang Allah kerjakan tidak hanya bagi manusia tetapi segala sesuatu. Implikasi dari hal tersebut adalah manusia sebagai agen Kerajaan Allah di tengah dunia turut menghadirkan rekonsiliasi tersebut pada masa kini bukan justru memperparah keadaan atau pasrah karena ciptaan Allah lainnya bukanlah objek penebusan. Dan yang terakhir garis penebusan manusia dan ciptaan Allah lainnya akan bersinggungan dengan garis kekekalan di akhir zaman.

Namun, penatalayanan ciptaan tentunya berdampingan dengan tantangan yang dihadapi. Mulai dari politik, ekonomi, agama hingga budaya. Tantangan tersebut juga menyadarkan bahwa persoalan lingkungan adalah persoalan yang kompleks. Pendekatan etis adalah salah satu bagian dari pendekatan lainnya untuk membaharui keadaan. Hasil penelitian ini diharapkan dapat digunakan sebagai bahan pertimbangan bagi orang kristiani dalam merefleksikan kembali persoalan pandemi Covid-19 dan tinjauan etis kristiani. Penelitian ini juga dapat menjadi referensi untuk penelitian lebih lanjut mengenai etika lingkungan, yang tentunya akan dalam waktu yang lama akan selalu menjadi topik penelitian karena persoalan lingkungan belum memperlihatkan tandatanda akan selesai tertangani.

${ }^{41}$ F. I. Rodriguez, "Reconstituting Damaged Ecologies: Ethics for Post-Colonial Development," Global Bioethics 11, no. 1-4 (January 10, 1998): 53, https://doi.org/10.1080/11287462.1998.10800730. 


\section{REFERENSI}

Alexander, John. "Environmental Sustainability versus Profit Maximization: Overcoming Systemic Constraints on Implementing Normatively Preferable Alternatives." Journal of Business Ethics, 2007. https://doi.org/10.1007/s10551-006-9264-5.

Alinurdin, David. "COVID-19 Dan Tumit Achilles Iman Kristen." Veritas: Jurnal Teologi Dan Pelayanan 19, no. 1 (June 8, 2020): 1-9. https://doi.org/10.36421/veritas.v19i1.373.

Ananta, Dicky Dwi. "Politik Oligarki Dan Perampasan Tanah Di Indonesia: Kasus Perampasan Tanah Di Kabupaten Karawang Tahun 2014." Jurnal Politik 2, no. 1 (October 15, 2017): 101-35. https://doi.org/10.7454/jp.v2i1.83.

Astrid. "Omnibus Law (RUU Cipta Kerja) Untuk Siapa?" Omnibus Law (RUU Cipta Kerja) Untuk Siapa?, 2020.

Ayre, Clive William. An Approach to Ecological Mission in and Through the Christian Community in Australia: Beyond Apathy to Committed Action. Queensland: University of Queensalnd, 2008.

The Economist. "Buying Farmland Abroad Outsourcing's Third Wave," 2009. https://www.economist.com/international/2009/05/21/outsourcings-third-wave.

Carrington, Damian. "Pandemics Result from Destruction of Nature, Say UN and WHO." The Guardian. London, June 2020. https://www.theguardian.com/world/2020/jun/17/ pandemics-destruction-nature-un-who-legislation-trade-green-recovery.

DeWitt, Calvin B. "Stewardship: Responding Dynamically to the Consequences of Human Action in the World." In Enviromental Stewardship. London: T\&T Clark, 2006.

Douglas, John Hall. The Steward: A Biblical Symbol Come of Age. Grand Rapids: Eerdmans, 1990.

Duchrow, Ulrich, and Gerhard Liedke Shalom. Biblical Perspectives on Creation, Justice \& Peace. Manila: WCC Publication, 1989.

Dwiraharjo, Susanto. "Konstruksi Teologis Gereja Digital: Sebuah Refleksi Biblis Ibadah Online Di Masa Pandemi Covid-19." EPIGRAPHE: Jurnal Teologi Dan Pelayanan Kristiani 4, no. 1 (May 29, 2020): 1. https://doi.org/10.33991/epigraphe.v4i1.145.

Emilia, Grace. "Afeksi Dalam Teologi Jonathan Edwards Serta Implementasinya Dalam Kehidupan Kristen." PASCA: Jurnal Teologi Dan Pendidikan Agama Kristen 16, no. 2 (November 5, 2020): 81-93. https://doi.org/10.46494/psc.v16i2.112.

Environmental Law, Indonesia Center. "Pelemahan Instrumen Perlindungan Dan Pengelolaan Lingkungan Hidup Dalam RUU Cipta Kerja." Pelemahan Instrumen Perlindungan Dan Pengelolaan Lingkungan Hidup Dalam RUU Cipta Kerja, 2020.

Es, General. "WEA GA Statement - On the Care of Creation." World Evangelical Alliance, 2008. https://worldea.org/es/news/wea-ga-statementon-the-care-of-creation/.

"'Evangelical Christianity and The Environment' World Evangelical Fellowship Theological Commission Unit on Ethics and Society/Au Sable Forum Summarizing Committee Report." Transformation: An International Journal of Holistic Mission Studies 9, no. 4 (October 1992): 27-30. https://doi.org/10.1177/026537889200900410.

Fund, World Wildlife. "The Loss of Nature and the Rise of Pandemics Protecting Human and Planetary Health," 2020.

https://wwfeu.awsassets.panda.org/downloads/the_loss_of_nature_and_rise_of_pandemics protecting_human_and_planetary_health.pdf.

Gnanakan, Ken. Responsible Stewardship of God's Creation. New York: World Evangelical Alliance, 2014.

Hadiz, Vedi. Dinamika Kekuasaan: Ekonomi Politik Indonesia Pasca-Soeharto. Jakarta: LP3ES, 2005.

Harefa, Otieli. "Implikasi Teologis Baptisan Air Pada Keselamatan." PASCA: Jurnal Teologi Dan Pendidikan Agama Kristen 16, no. 1 (May 29, 2020): 1-14.

https://doi.org/10.46494/psc.v16i1.78. 
Keenan, Rodney J., Gregory A. Reams, Frédéric Achard, Joberto V. de Freitas, Alan Grainger, and Erik Lindquist. "Dynamics of Global Forest Area: Results from the FAO Global Forest Resources Assessment 2015." Forest Ecology and Management 352 (September 2015): 920. https://doi.org/10.1016/j.foreco.2015.06.014.

Kraybill, Donald. Kerajaan Yang Sungsang. Jakarta: BPK Gunung Mulia, 2005.

Kurniawan, Fajar. "Problematika Pembentukan RUU Cipta Kerja Dengan Konsep Omnibus Law." Jurnal Panorama Hukum, 2020. https://doi.org/10.21067/jph.v5i1.4437.

Ludji, Irene. "Spiritualitas Lingkungan Hidup: Respon Iman Kristen Terhadap Krisis Ekologi." In Respon Agama Kristen Terhadap Kerusakan Lingkungan, 63-78. Yogyakarta: UKSW, 2014.

Manusama, Ledy. "Allah Dan Alam." KENOSIS: Jurnal Kajian Teologi 1, no. 2 (2015): 187-203. https://doi.org/https://doi.org/10.37196/kenosis.v1i2.28.

Matompo, Osgar Sahim, and Wafda vivid Izziyana. "Konsep Omnibus Law Dan Permasalahan RUU Cipta Kerja." Rechstaat Nieuw (Aturan Hukum Baru), 2020.

Moltmann, Jürgen. God in Creation: A New Theology of Creation and the Spirit of God. Gifford Lectures ; 1984-1985, 1991.

Money, Roy. "A Network of Mutuality." In In an Inescapable Network of Mutuality: Martin Luther King, Jr. and the Globalization of an Ethical Ideal, edited by Lewis V. Baldwin and Paul R. Dekar. Oregon: Cascade Books, 2013.

Prasetia, Andhika. "Genjot Pariwisata Di Tengah Corona, Jokowi Beri Turis Diskon." Detiknews. February 2020. https://news.detik.com/berita/d-4903193/genjot-pariwisata-ditengah-corona-jokowi-beri-turis-diskon.

Rae, Murray. "To Render Praise: Humanity in God's World." In Enviromental Stewardship, edited by Robert James Berry, 291-312. Edinburgh: T\&T Clark, 2006.

Rahayu, Ani Sri. "Omnibus Law Cipta Kerja Atau Cilaka?" Arsip Publikasi Ilmiah Biro Administrasi Akademik, 2020.

Remikatu, Jefri Hina. "Teologi Ekologi: Suatu Isu Etika Menuju Eskatologi Kristen." CARAKA: Jurnal Teologi Biblika Dan Praktika, 2020. https://doi.org/10.46348/car.v1i1.12.

Rodriguez, F. I. "Reconstituting Damaged Ecologies: Ethics for Post-Colonial Development." Global Bioethics 11, no. 1-4 (January 10, 1998): 47-56. https://doi.org/10.1080/11287462.1998.10800730.

Silitonga, Roedy. "Respon Gereja Atas Pandemik Corona Virus Desease 2019 Dan Ibadah Di Rumah." Manna Rafflesia 6, no. 2 (April 30, 2020): 86-111. https://doi.org/10.38091/man_raf.v6i2.125.

Stevanus, Kalis. "Pelestarian Alam Sebagai Perwujudan Mandat Pembangunan: Suatu Kajian Etis-Teologis." KURIOS (Jurnal Teologi Dan Pendidikan Agama Kristen) 5, no. 2 (2019): 94-108.

Tampubolon, Yohanes Hasiholan. "Refleksi Kepedulian Injili Pada Isu Lingkungan Hidup." Stulos 18, no. 1 (2020): 53-76.

__. "Telaah Kritis Etika Lingkungan Lynn White." TE DEUM (Jurnal Teologi Dan Pengembangan Pelayanan), 2020.

Tidball, Derek J. Teologi Penggembalaan (Suatu Pengantar). Malang: Gandum Mas, 2020.

Wardhani, Lavandya Permata Kusuma, and Daniel Fajar Panuntun. "Pelayanan Pastoral Penghiburan Kedukaan Bagi Keluarga Korban Meninggal Coronavirus Disease 2019 (COVID-19)." KENOSIS: Jurnal Kajian Teologi 6, no. 1 (June 15, 2020): 43-63. https://doi.org/10.37196/kenosis.v6i1.98.

Winters, Jeffrey A. "Oligarki Dan Demokrasi Di Indonesia." Majalah Prisma 33, no. 1 (2014). Wittmer, Michael. Heaven Is A Place On Earth. Grand Rapids: Zondervan Publishing, 2004. Yuono, Yusup Rogo. "Etika Lingkungan: Melawan Etika Lingkungan Antroposentris Melalui Interpretasi Teologi Penciptaan Yang Tepat Sebagai Landasan Bagi PengelolaanPelestarian Lingkungan." FIDEI: Jurnal Teologi Sistematika Dan Praktika, 2019. https://doi.org/10.34081/fidei.v2i1.40. 